\title{
A Profound Impact of Covid-19 on Online Shopping Modality in Coimbatore City
}

\author{
Mrs.S.Mahalakshmi ${ }^{1}$, Dr.E.Muthu Kumar ${ }^{2}$ \\ ${ }^{1}$ Research Scholar, Bharathiyar University \& Assistant Professor, Sri Krishna Arts and Science College, \\ Coimbatore, Tamil Nadu. \\ ${ }^{2}$ Associate Professor, Nehru College of Management, Coimbatore, Tamil Nadu
}

\begin{abstract}
The coronavirus (COVID-19) outbreak is first and prime human disaster across the globe, upsetting the lives of lots of people. It has greatly impacted the worldwide economy. This paper is projected to provide business Experts with a view on the developing situation and allegations on the consumer as well. Every sphere is affected and impacted by the pandemic. Before lockdown work from home twisted a positive shift in the trend of online shopping. But this could not exist in for a long time. Unforeseen lockdown of 21 days impacted globe online shopping and marketing drifts drastically. Initially, Coronavirus's stimulus on consumer purchasing behaviour, towards brands and online gears was largely unknown. This paper aims to reflect on different issues and viewpoints of online marketing due to COVID-19. There are still many more doubts to predict how the sale for the next few months will be affecting the worldwide community, both personally as well as professionally.

This study explores the impact of the rampant in many more daily rudiments. Although some of the companies succeeded to operate through social commerce that is marketing by using e-commerce and social media. societal networks are important for information sharing and for making product choices. But results are suggestive of the fact that online marketing and shopping will soon go back to normal but the victims and downshift fetched by this pandemic are not disregardable.
\end{abstract}

Keywords: Customer Behaviour, E-Customers, Buying Behaviour, Online-Shopping, widespread, Pandemic.

\section{INTRODUCTION}

In India, a great majority of B2C ecommerce retailers, draw customers to shop online by offering bargains such as free delivery, discounts, buy-one-get-one-free and exchange offers. However, many Indian shoppers known to be costconscious and conservative as a part of their value system, are generally not attracted into making quick decisions based on promotions and advertisements. Moreover, online shoppers, many-a-times, come across problems concerning product delivery timelines and customer support services. Customers' awareness of risk toward online web sites is aggravated due to the inferior IT set-up used by several e-tailers, resulting in hacking of personal information.

\subsection{Need for study}

The study aims to measure customer perception regarding online shopping during covid-19 in Coimbatore city. The area within which the study was conducted regarding the information the primary data is collected in the form of questionnaire collected from the customers in Coimbatore district. To sum up the project had within the scope of the study in the area of "Customer Buying Awareness" towards online shopping in Coimbatore city for a particular time after post covid 19 lockdown. The study measures the experiences of customers. Defines and analyses the experiences based on key deliverables. Gains insights into Customer expectations.

\subsection{Objectives}

- $\quad$ To study the functions influencing the customer towards online shopping after post lockdown.

The following are the secondary objectives of the study

- $\quad$ To analyze the opinion about shopping in the online portal during post lockdown

- $\quad$ To measure the level of satisfaction during online purchase in Coimbatore city 


\subsection{Scope of the Study}

- The scope of this study is to access and evaluate various aspects of the buying perception of customers during online shopping in covid 19 period.

- To know about the factors that influences the customer's decision to use online shopping in pandemic situation in Coimbatore city.

- To know about the attributes that a customer's look for in the online shopping in while purchasing.

\subsection{Limitations of the Study}

- Due to very large size of the population, only a selected sample of customer could be contacted.

- Personal biases might have come while answer the questionnaire.

\section{REVIEW OF LITERATURE}

Tasin Islam (2018), The online marketing actions play a large role in creating brand alertness as well as help maintain a fitting together between the consumers and the sellers in this case. The online retailers need to make the utmost practice of this free, but extensive medium, which will play a vivacious role in the voyage of the brand itself. A lot of emphasis also needs to be put on the pricing and the sanctuary measures, as this will generate a rising consumer base as well as customer loyalty, which will help the brand reach a safe sector in its lifespan.

Dr. S. Hariharan (2018) states that majority of the consumers perceived positively and they were very much satisfied in online shopping. On the other hand the consumers are facing more problems during shopping online. Hence the policy makers can utilize the suggestions of this study to enhance the redressal mechanism to resolve the problems faced by the consumer during online shopping to switch the consumers to customers.

Monsuwe, Delleart and Ruyter, (2018) Consumer's intention to return should increase as the extent a consumer assistant enthusiasm with an e-tailer increase; as the psychological cost reduces, the shopping experience will be more enjoyable and therefore creates excitement. Consumers will have more positive attitude when they enjoy the experience of online shopping and are more likely to adopt internet as a shopping medium; potential of entertainment of online shopping will reflect consumers' enjoyment.

\section{RESEARCH METHODOLOGY}

\subsection{Research Design}

The Main focus of the research is to study the influencing the customer towards online shopping after post lockdown. It was therefore, decided to use descriptive research is used for this investigation. It is otherwise known as explanatory design. The descriptive study is typically concerned with determining frequency with which relationship occurs or how two variables vary between them.

\subsection{Sample Size}

The researchers have selected the sample size to be 100 from online users.

3.3 Sampling Method

The researchers have taken convenience sampling method among the customers in Coimbatore City for collecting the response.

3.4 Tools for analysis

The appropriate tools will be used for analysis

3.5 Percentage analysis: It is applied to create a contingency table from the frequency distribution and represent the collected data for better understanding.

$$
\text { Formula for Percentage Analysis }=\frac{\text { Respondents }}{\text { Total no. of Respondents }}
$$

\section{DATA ANALYSIS \& INTERPRETATION}

\subsection{Online shopping of the respondents}

\begin{tabular}{|c|c|c|c|c|c|}
\hline \multicolumn{6}{|c|}{ Online shopping of the respondents } \\
\hline S.no & Particulars & Frequency & Percent & $\begin{array}{l}\text { Valid } \\
\text { Percent }\end{array}$ & $\begin{array}{l}\text { Cumulative } \\
\text { percent }\end{array}$ \\
\hline 1 & Once in a Week & 16 & 16 & 16 & 16.0 \\
\hline 2 & Once in 1-2 months & 33 & 33 & 33 & 49.0 \\
\hline
\end{tabular}


International Advanced Research Journal in Science, Engineering and Technology

Vol. 8, Issue 9, September 2021

DOI: 10.17148/IARJSET.2021.8968

\begin{tabular}{|l|l|l|l|l|l|}
3 & 2 weeks once & 25 & 25 & 25 & 74.0 \\
\hline 4 & More than once in a month & 26 & 26 & 26 & 100.0 \\
\hline & Total & 100 & 100 & 100 & \\
\hline
\end{tabular}

\section{Interpretation:}

The above table show the respondents of online shopping more than once in a Week are 16 percent, Once in 1-2 Months 33 percent, 2 weeks once are 25 percent and more than once in a month purchased are 26 percent.

Inference:

The majority of respondents purchase once in 1-2 months is $33 \%$

Figure 4.1

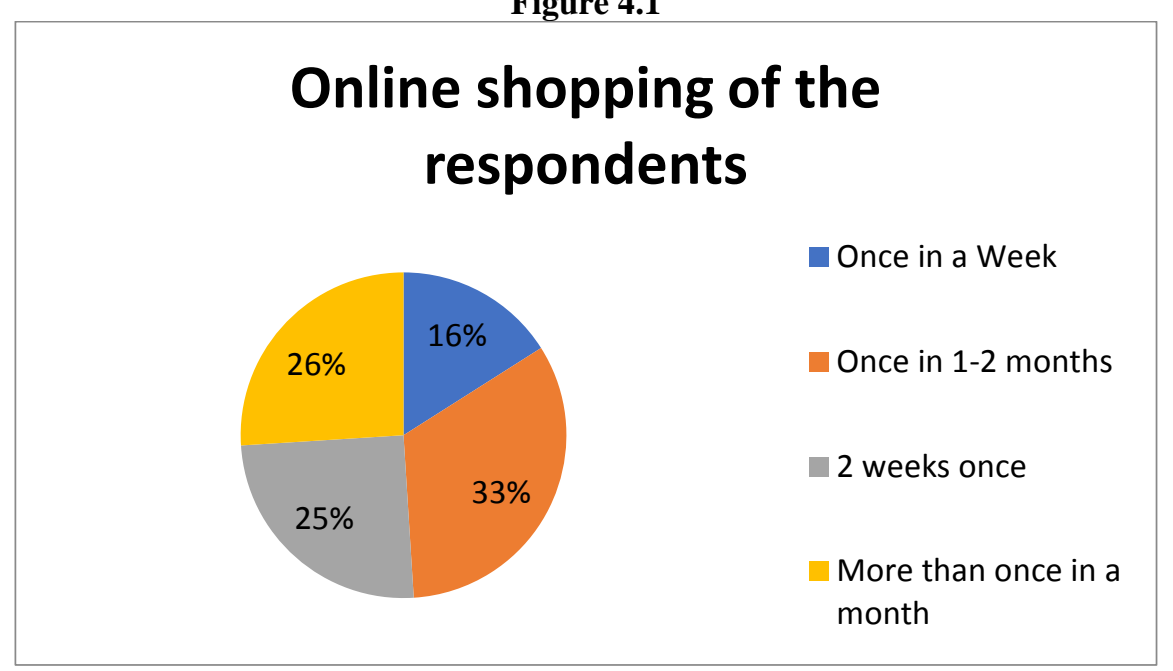

4.2 Products purchased by the respondents

\begin{tabular}{|l|l|l|l|l|l|}
\hline \multicolumn{6}{|l|}{ Products purchased by the respondents } \\
\hline S.no & Particulars & Frequency & Percent & $\begin{array}{l}\text { Valid } \\
\text { Percent }\end{array}$ & $\begin{array}{l}\text { Cumulative } \\
\text { percent }\end{array}$ \\
\hline 1 & Electronic Goods & 20 & 20 & 20 & 20.0 \\
\hline 2 & Cosmetics & 16 & 16 & 16 & 36.0 \\
\hline 3 & Grocery items & 38 & 38 & 38 & 74.0 \\
\hline 4 & $\begin{array}{l}\text { Fruits and } \\
\text { Vegetables }\end{array}$ & 26 & 26 & 26 & 100.0 \\
\hline & Total & 100 & 100 & 100 & \\
\hline
\end{tabular}

\section{Interpretation:}

The above table show the products purchased frequently by the customer Grocery items are 38 percent, Fruits and vegetables are 26 percent, Electronic Goods are 20 percent, and Cosmetics are 16 percent.

\section{Inference:}

Major respondents frequently purchase Grocery Items 38\% 
DOI: $10.17148 /$ IARJSET.2021.8968

Figure 4.2

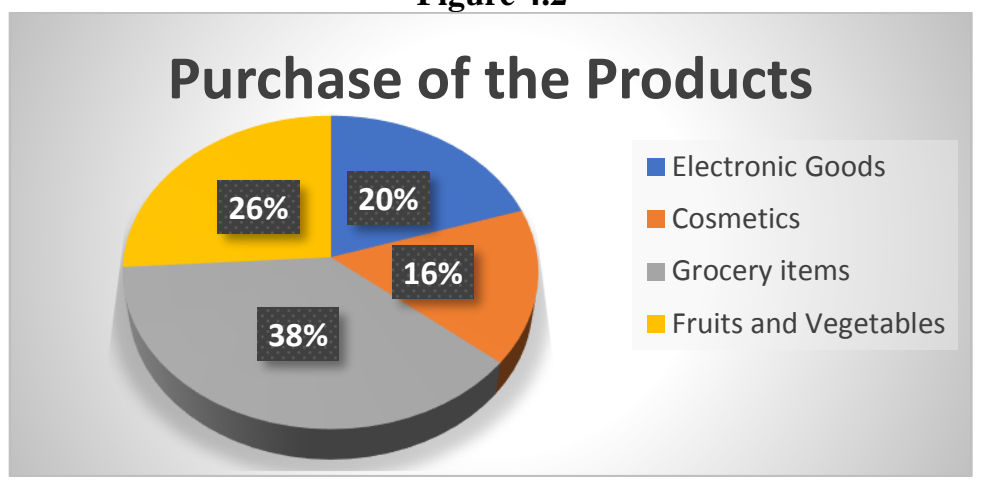

4.3 Chi-Square Analysis: Chi-square is a statistical test commonly used to compare observed data with data we would expect to obtain according to a specific hypothesis
Where
O - Observed Value

$$
\text { Chi }- \text { square }=\sum \frac{(0-E)^{2}}{E}
$$

\subsection{Chi-Square Test}

Frequency of purchase * Factors influencing the customer in online shopping
Cross tabulation

Chi-Square Tests

\begin{tabular}{|l|l|l|l|}
\hline & Value & Df & Asymp. Sig. (2-sided) \\
\hline $\begin{array}{l}\text { Person Chi- } \\
\text { Square }\end{array}$ & 23.909 & 9 & .004 \\
$\begin{array}{l}\text { Likelihood } \\
\text { Ratio } \\
\text { No of Valid } \\
\text { Cases }\end{array}$ & 25.088 & 9 & .003 \\
\hline
\end{tabular}

a. 7 cells $(43.8 \%)$ have expected count less than 5 . The minimum expected count is .36

\section{Interpretation:}

The calculated value $0.004<0.05$. Hence null hypothesis is accepted. So there is no significant relationship between frequency of online shopping and the factors influences the customer purchase through online.

\section{Inference}

The test has proved that there is no significant relationship between frequent buying through online shopping and factors influence the customer shopping through online. 


\section{International Advanced Research Journal in Science, Engineering and Technology}

Vol. 8, Issue 9, September 2021

DOI: $10.17148 /$ IARJSET.2021.8968

\section{CONCLUSION}

Since the online business is at the tiller of the economy, the research has shown the customer satisfaction of Online shopping in Coimbatore city. Since the consumer customer satisfaction is the important factor to forecast the sales of any product in a particular area. So company should keep close eye on the market situation. yet, customers were price sensitive, but the changing market trend and customer view and preference shown that customer are now quality sensitive. They want quality product, good services, easy availability of product and better performance by the product. These days no of customer buying from online has been increased. Also the frequency to visit the online web portal for purchasing has been increased substantially. People are more brands conscious and they are satisfied with the range of products available in online.

\section{.REFERENCES}

1. Kothari, C. R., \& Garg, G. (2019). Research methodology: Methods and techniques. New Age International (P) Limited, Publishers.

2. Tasin Islam (2018), Factors Affecting Consumer Purchase Behavior Towards Online Clothing Products in Bangladesh, November 2, 2018

3. Dr. S. Hariharan (2018), Consumer Perception Towards Online Shopping With Reference To Tirupattur, International Journal of Pure and Applied Mathematics, Volume 119 No. 18, 2018,pp (3353-3361). 